Eğri, S. (2022). Ali Behcet Dede: Cana şifa kahvesi ve gönüllere deva manzumesi. Uludağ Üniversitesi Fen-Edebiyat Fakültesi Sosyal Bilimler Dergisi, 23(42), 17-43.

DOI: 10.21550/sosbilder.1000215

Araştırma Makalesi / Research Article

\title{
ALİ BEHCET DEDE: CANA ŞIFA KAHVESİ VE GÖNÜLLERE DEVA MANZUMESİ
}

Sadettin EĞRI'

Gönderim Tarihi / Sending Date: 24 Eylül / September 2021

Kabul Tarihi / Acceptance Date: 28 Ekim / October 2021

\section{ÖZET}

Türk edebiyat tarihinde pek çok şair ve müellif geride bıraktı̆̆ eserleriyle anılır. Kimi zaman şair ve mutasavvıflar arasında latif nükteler ortaya çıkar. Sohbet esnasında bir şairin sözü veya hareketi neticesinde mecliste bulunan bir şair o durumu misralarlyla ebedîleştirir. Nitekim ünlü mutasavvif ve şair Ali Behcet Dede'nin böylesi bir ortamda elleriyle kahve yapıp, ikram etmesi sebebiyle bu hâlden etkilenen Hüseyin Vassâf ve Rızâ Bey, muhabbet ve saygı duyduklarl Ali Behcet'e birer misra söylerler. Şiirde onun kahvesinin canlara şifa, şiirlerinin de gönüllere deva olduğunu ifade ederler. Bunun üzerine beş farkl tarikattan manevi eğitim alan Ali Behcet Efendi, bu misralara irticâlen kendi beyitlerini ekler. Birçok esere sahip olan Ali Behcet Efendi'nin şiirleri dağınık hâldedir. Bu çalışmada şairin -bir divan oluşturacak hacimde ve özellikte olmayan-şiirleri ve bu latif olay ele alınıp, bir araya getirilmiş ve incelenmiştir.

Anahtar Kelimeler: Ali Behcet, kahve, Hüseyin Vassâf, Mehmed Şemseddîn, latife

\section{Ali Behcet Dede: Healing Coffee for The Soul and A Cure for The Hearts}

\begin{abstract}
In the history of Turkish literature, many poets and authors are remembered for the works they left behind. Sometimes, pleasant wit appears between poets and mystics. As a result of a poet's word or action during the conversation, a poet who is in the assembly eternalizes that situation with his verses. As a matter of fact, Huseyin Vassaf
\end{abstract}

Doç. Dr., Bursa Uludağ Üniversitesi Fen-Edebiyat Fakültesi Türk Dili ve Edebiyatı Bölümü, Bursa / TÜRKIYE, sadettin@uludag.edu.tr

Uludağ Üniversitesi Fen-Edebiyat Fakültesi Sosyal Bilimler Dergisi Uludağ University Faculty of Arts and Sciences Journal of Social Sciences

Cilt: 23 Sayı: 42 / Volume: 23 Issue: 42 
and Riza Bey, who were affected by the famous sufi and poet Ali Behcet Dede's making and serving coffee in such an environment, sing a verse each to Ali Behcet, whom they love and respect. In poetry, they express that his coffee is healing for souls and his poems are a cure for hearts. Thereupon, Ali Behcet Efendi, who received spiritual training from five different sects, adds his own couplets to these verses. The poems of Ali Behcet Efendi, who has many works, are scattered. In this study, the poet's poems that are not in the volume and feature to form a divan and this beautiful event are discussed, brought together and examined.

Key words: Ali Behcet, coffee, Huseyin Vassaf, Mehmed Semseddin, joke

\section{Giriş}

Türk edebiyatında şairlerin eserleri dışında yaşantıları esnasında aralarında hoş latifeler, nükteler ve müşâarelerle dolu hatıralar ve tebessüm ettirecek edebî hâller de meydana gelirdi. Bir sohbet esnasında veya bir şiir vesilesiyle edebiyat tarihinde iz bırakabilecek muhabbetler ile konuyla bağlantılı manzumeler ortaya çıardı. Okuyucuyu veya dinleyicileri tebessüm ettiren latif ve nükteli söyleyişler, tasavvuf kültürünün ilginç sayfaları olarak günümüze kadar gelmiştir. İnsan ruhunun en önemli özelliklerinden hatta ihtiyaçlarından biri de; gülmek, şakalaşmaktır. Günlük hayatta yaşanılan olayların, hiç olmazsa, tebessümle karşılanması, adeta, hayatın bir gereği olarak düşünülebilir. $\mathrm{Bu}$ gereklilik, aslında, hayata bakış açısının bir tezahürüdür. Bu tezahürün diğer cephesinde ise üzüntü, sabır, tevekkül gibi başka unsurlar da vardır. İşte bunların tamamı, insanın hayat felsefesini ortaya koyar. Olayları tebessüm ile karşılayabilmenin yolu, mizahtan geçer. Mizah, bir mizaç işidir, aynı zamanda insandan zekâ da ister. Mizah kavramının yanı sıra bu gün "şaka, eğlence, latife, nükte, fikra" kavramlarının da dilimizde kullanıldığını görüyoruz. "Alay etme, dalga geçme, istihza ve hicvin" yanı sıra Fransızcadan alınan espri de günlük dilde bu anlamda kullanılan kelimeler arasına girmiştir. Eski edebiyat da denilen klasik edebiyatta bu anlama gelen Klasik Türk Edebiyatında söz konusu mizahi anlatılar için "hezl, mutâyebe, 
mülâtafe, ta'riz, nekre" gibi kelimelerin kullanıldığ 1 bilinmektedir (Solmaz, 2011: 17-18).

Gelişen bir olay neticesinde olayın kahramanları ve sohbete dâhil olan kişilerin yüzünde hoş bir tebessüm bırakan latife, nükte, gülmeceler özellikle edebiyat tarihimizin ele alınması gereken sayfalarıdır. $\mathrm{Bu}$ konuları ele alan müstakil eserlerin yanı sıra divanlardaki farklı biçim ve içerikte yazılmış latife ya da hezl şiirlerinin de bu türün özelliklerinin daha iyi belirlenebilmesi için incelemeye değer olduklarını söyleyebiliriz (Batislam, 2013: 238). Bir güldürü ve yerme şairinin küçük bir kıt'ası, yoğunlaştırılmış özlü anlamı, sert ve keskin deyişiyle, sayfaların anlatamayacağı oranda etki yapar (Levend, 1971: 37).

Ali Behcet Efendi'nin bir sohbet esnasında dostlarına kahve yapıp ikram etmesi sırasında söylenen "Behcet Dede'nin kahvesi bin câna bedeldir" mısra1, dikkatimizi çekince, şahsiyetini ve dağınık hâldeki şiirlerini incelemeye karar verdik. Bu mısra, bazı kaynaklarda Hüseyin Vassâf'a atfen "Behcet Dede'nin kahvesi pek tatlı imiş" şeklinde geçmektedir. Hayatı ve hoş kişiliği yanında nükteli şiirleri ile de kendinden bahsettiren Ali Behcet Efendi'nin dağınık vaziyette şiirleri mevcuttur. Pek çok ünlü mutasavvıf ve şairle dostluk kuran Behcet Efendi; âlim, mutasavvıf ve şair kimliğiyle kültür tarihimizde yerini almıştır. İstanbul Üniversitesi Marmara İlahiyat Fakültesi Kütüphanesi no. 250'de bulunan ve Hafiz Ali Üsküdarlı tarafından vakfedilen yazma bir risalede Ali Behcet Efendi'nin 12 şiiri bulunmaktadır. Ayrıca Nûreddîn Cerrâhî Âsitânesi son postnişini Fahreddîn Efendi'nin kişisel evrakı arasında bulunan Hazret-i Pîr Muhammed Nûreddîn Cerrâhî hakkında yazılmış olan bir şiiri incelenmiştir. Ali Behcet Efendi'nin kendi el yazısıyla 3 adet mektubu vardir. 


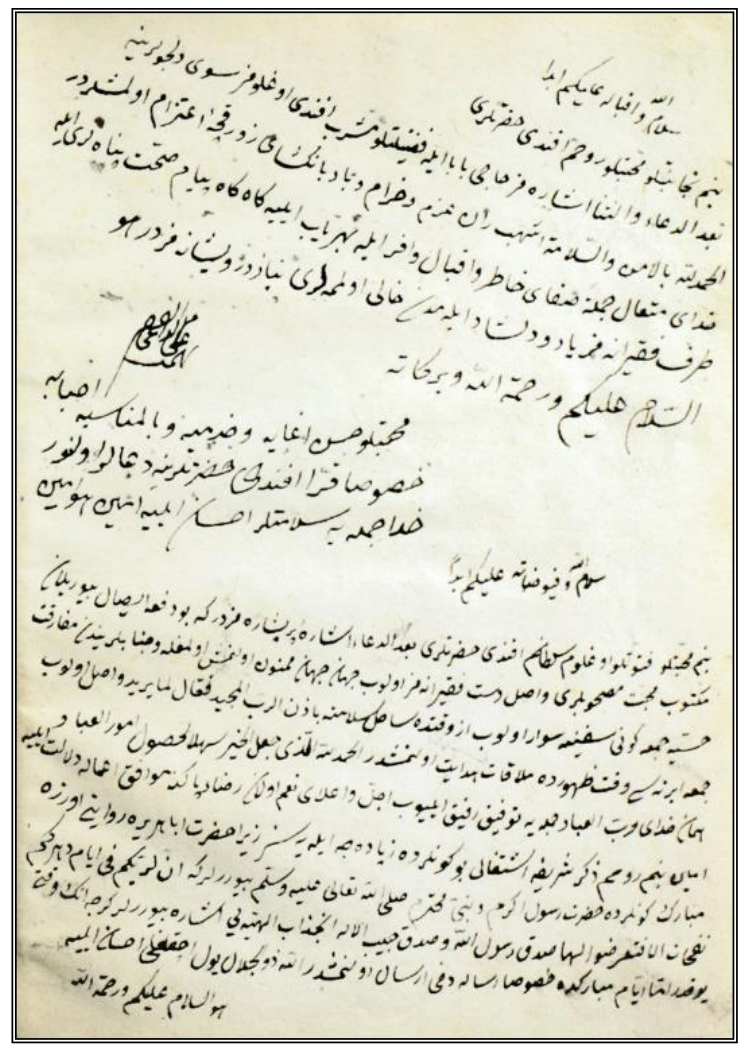

Ali Behcet Efendi’nin Mektubu

\section{Ali Behcet Efendi (1727-1822/1823)}

Ali Behcet Efendi, önemli sûfî ve şairlerinden biridir. Ali Behcet bin Ebî Bekr bin Hasan bin Hüseyn künyesiyle bilinen şair, h.1140/22 Ekim 1727 tarihinde Konya'da dünyaya gelmiştir. Babasının adı Ebu Bekir, dedesi ise Hasan Efendi'dir. Ali Behcet Efendi, ilk eğitimini devrin âlimlerinden olan Dedesi Hasan Efendi'den almıştır. Daha sonra Karamanlı Abdullah ve Abdussamed Efendi'den ders almıştır. Bu eğitimlerini tamamlayan Behcet Dede, Afyonkarahisar'a gidip Divane

Uludağ Üniversitesi Fen-Edebiyat Fakültesi Sosyal Bilimler Dergisi Uludağ University Faculty of Arts and Sciences Journal of Social Sciences Cilt: 23 Sayl: 42 / Volume: 23 Issue: 42 
Mehmed Çelebi Dergâhı postnişini Mehmed Alâaddîn Çelebi'den tasavvufa ait eserleri okumuştur.

Ali Behcet Efendi'nin kişiliği ve hayatı hakkında en ayrıntılı bilgiyi Hüseyin Vassâf Sefinne-i Evliyâ adlı eserinde vermiştir (Hüseyin Vassâf, 2000: 208). Ali Behcet Efendi önce kadılık göreviyle farklı şehirlerde görev yapmış, daha sonra Ankara niyabetinde iken kendisinde zuhur eden manevi bir hâl üzerine memuriyetten ayrilıp tekrar Afyon'daki Alâaddîn Çelebi'ye intisap etmiş̧ir. "Çile"sini tamamlayıp, sikke giyen Ali Behcet Efendi; Bursa'da Abdulkâdir Geylânî soyundan olan Kerküklü Seyyid Burhâneddîn Mehmed Emin Efendi'ye (1719?-1813?) intisap ederek Nakşibendiyye, Kâdiriyye, Kübreviyye, Sühreverdiyye, Çeştiyye ve Şüttâriyye icazetleri almıştır. Şeyh Mehmed Emin Efendi, sağlığında herhangi bir eser yazmamıştır ancak yetiştirmiş olduğu talebe ve müridleri, eserleriyle ve görüşleriyle bir döneme damga vurmuşlardır. Şeyhin, müridlerinden tespit edilenlerin biri de Selimiye Tekkesi Şeyhi Ali Behcet Efendi'dir (öl. 1238/1822) (Öcalan, 2018: 219).

Ali Behcet Efendi, Bursa'da sürgün hayatı yaşayan ve daha sonra affedilen Sadrazam Burdurlu Derviş Mehmed Paşa'nın tavsiyesiyle II. Mahmud tarafindan İstanbul'a davet edildi ve III. Selim'in yaptırdığı Üsküdar'daki Selimiye Nakşibendi Dergâhı şeyhliğine tayin olundu (1816). Tasavvuf tarihinde birbirine zit temayüllere sahip Nakşibendiyye'den Müceddidiyye ile Mevleviyye tarikatlarına mensup olmakla birlikte Nakşibendi şeyhi olarak faaliyet gösterdi. II. Mahmud devrinin önemli devlet adamları, âlim ve aydınları katında büyük bir nüfuza sahip oldu. Kendisine intisap eden Mehmed İffet, Mehmed Rifkı, Halet Efendi, Pertev Paşa, Kethüdazade Arif, Şeyhülislam Turşucuzade Ahmed Muhtar bunlar arasında sayılabilir (Fatîn Davud, 2017: 189, 316). 


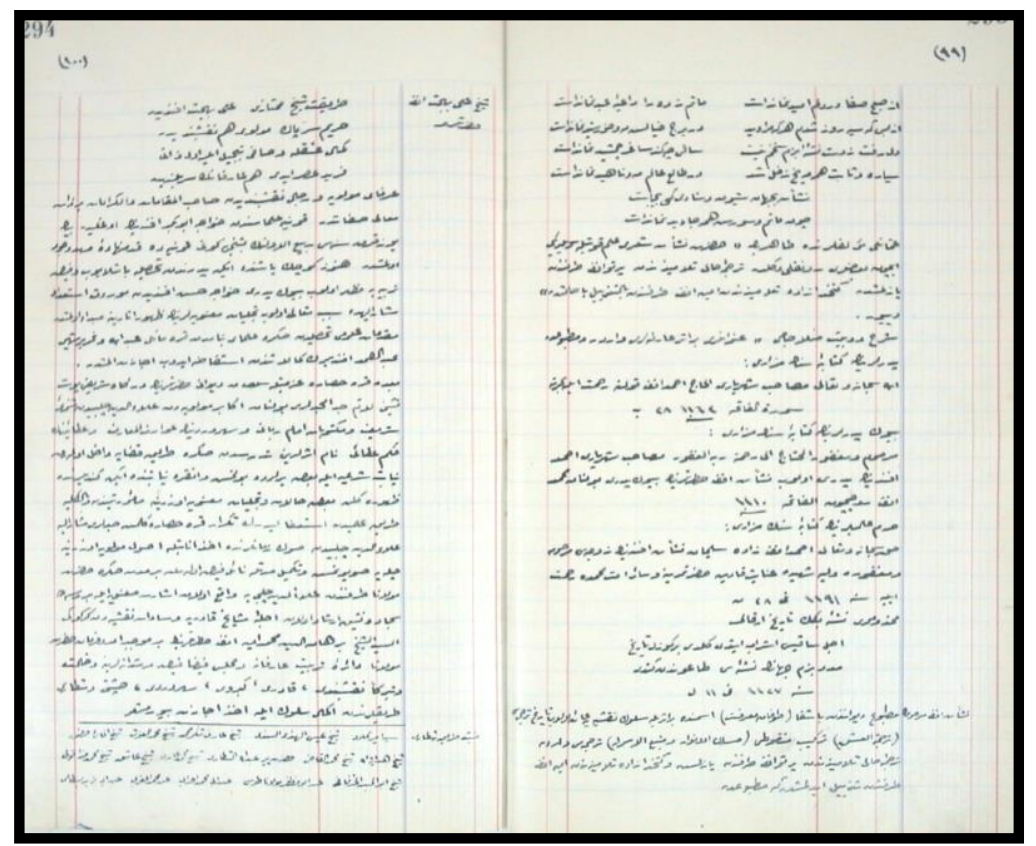

Hüseyin Vassâf, Sefine-i Evliyâ, s. 294.

XIX. yüzyılda Mevlevi-Nakşî yakınlaşmasında önemli bir yeri olan Şeyh Ali Behcet Efendi, ölümüne kadar irşad faaliyetinde bulunarak tâliplere tefsir, hadis, fikıh, Mesnevi ve Mektûbât okuttu (Günaydın, 2012: 9-15). Sadece dört kişiye (İbrahim Hayrânî, Mülkiye Nazırı Pertev Paşa, Ahmed Buharî Dergâhı şeyhi Rıfkı Efendi ve Hacı Ahmed) hilafet verdi. Büyük oğlu yetişinceye kadar halife olarak yerine İbrahim Hayranî Efendi’yi bıraktı. Kabri Selimiye Camii haziresindedir (Azamat, 1989: 382-383; Mehmed Süreyya, 1999: 33; Hüseyin Vassâf, 2006: 193).

Ali Behcet Dede'nin vefatına halifelerinden olan Mülkiye Nâzırı Muhammed Saîd Pertev Paşa şu manzum tarihi yazmıştır: 
Ey olan muntazır-ı feth-i kilîd-i esrâr

Dîde-i cânını kıl halka-i bâb-ı Behcet

Hâk-i dergâhı idüp sürme-i çeşm-i hak-bîn

Göresin nidüğini feyz-i Cenâb-ı Behcet

2 Cemaziye'l-Evvel 1238 (15 Ocak 1823)

(Çiçekçi Küçük) Selimiye Tekkesi Camii’nin avlu cümle kapısının hemen solunda, diğerlerinden daha büyük olan pencere Şeyh Ali Behçet Efendi'nin kabrine açılan bir niyaz penceresidir. Bu açıklığın üzerinde ta'lik hattı yine Yesârizâde'ye ait, adı geçen şeyhe ithaf edilmiş manzum bir kitâbe yer alır. Bu pencerenin solundaki ilk iki pencere, farklı boyutları ve mermer söveleriyle Ali Behçet Efendi'nin haleflerine ait mezarlara açılan tâli niyaz pencereleridir (Tarihi Eserleriyle Üsküdar, 2017: 167-169).

Beyaz benizli, uzun boylu, seyrek ve beyaz sakallı, sık kaşl1, gözleri ela diye tarif edilen Ali Behcet Efendi, daima sikke-i Mevlevî giyerler idi. 


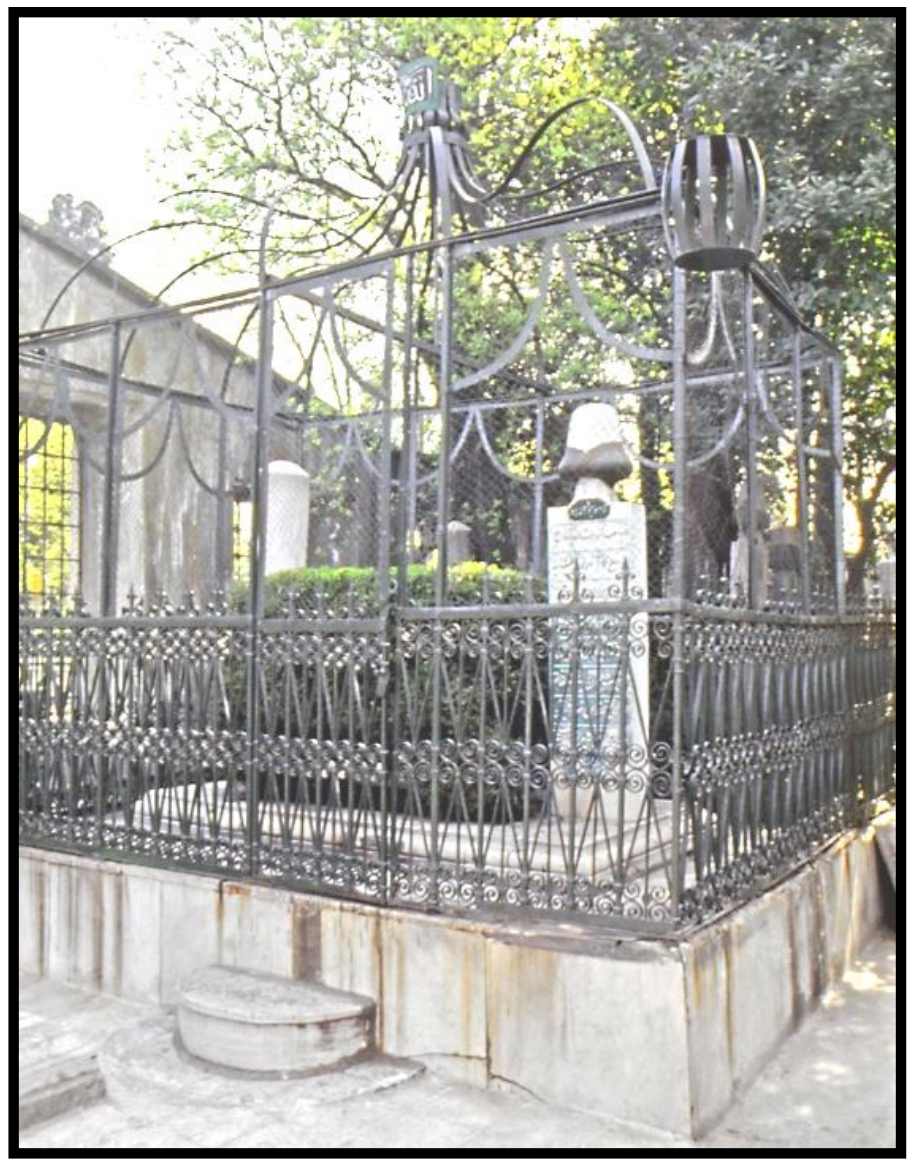

Ali Behcet Efendi’nin Üsküdar'daki Mezarı

Hüseyin Vassâf ve Bursalı Mehmed Tahir, Ali Behcet Efendi'nin Risale-i Ubeydiyye-i Nakşibendiyye, Behcetü's-Sülukk, Sirrü'l- Mîâd, Terceme-i Hâl-i Ricâl-i Çişstiyye, Risâle-i Hâliyye ve Ruhâniyye, Divançe ve Vâridât-l Kalbiyye adlı eserleri olduğunu kaydetmektedir (Hüseyin Vassâf, İstanbul 1333/1915, c. 1, s. 47; Bursalı Mehmed Tahir, 1972: 63-64). Bunlardan, Nakşibendiyye'nin

Uludağ Üniversitesi Fen-Edebiyat Fakültesi Sosyal Bilimler Dergisi Uludağ University Faculty of Arts and Sciences Journal of Social Sciences Cilt: 23 Sayı: 42 / Volume: 23 Issue: 42 
sülûk usulünden bahseden ve kendisinin Nakşibendî-Mevlevî silsilesini veren Risâle-i Ubeydiyye-i Nakşibendiyye basılmıştır (İstanbul, 1260). Günümüz harfleriyle Ubeydiye Risalesi ismiyle yayımlanmıştır (Günaydın, 2012). Kendi el yazısıyla üç mektubu ve bir manzumesi İstanbul Üniversitesi Kütüphanesindedir.

Hüseyin Vassâf' ın gerek Dîvân'ında gerekse Sefîne-i Evliyâ adlı eserinde çok sevdiği ve şeyhim dediği Ali Behcet Efendi için muhabbetleri ve hüsn-i nazarları vardı. Onunla ilgili pek çok nükteli ifadeler kullanmış ve şiirler yazmıştır. Osmanzâde Hüseyin Vassâf' in Sefine-i Evliyâ adlı eserinde yer alan aşağıdaki dörtlük o şiirlere bir örnektir:

Tarîkat Şeyh-i mümtâzı Ali Behcet Efendi'dir

Harîm-i sirr-ı pâk-i Mevlevî hem Nakşıbendî' dir

Kemâl-i aşkla Vassâf'ı tebcîl eyler ol zâtı

Ferîd-i asr idi hem ârifânin ser-bülendidir (2006: II, 193)

Hüseyin Vassâf, aralarında kırk seneden fazla hukuk ve muhabbet bulunan Şeyh Hacı Ali Behçet Efendi ile Tâhir Ağa Dergâhı'nda sohbette bulunmuştur. Özellikle burada medfûn bulunan Şeyh Selahaddîn-i Uşşâkî nâmına âşıklara hizmet etmiştir. Kendisi Behçet Efendiyle aralarındaki muhabbeti "Tâhir Ağa Dergâhı Şeyhi elHâc Ali Behcet Efendi Hazretlerine" başlığıyla ithâf ettiği bir gazelinde şöyle dile getirmiştir:

Nakşbendî gülüdür Hazret-i şeyhim Behcet

Reh-i aşk bülbülüdür Hazret-i şeyhim Behcet

Bezm-i tevhîde verir neş'eyi hâlâtı ile

Aşk-ı Hak'la doludur Hazret-i şeyhim Behcet

Mazhar-ı zevk-i hakîkî olarak feyz-âver

Kâdirî Sünbülîdir Hazret-i şeyhim Behcet

Revnak-efzâ-yı dil ü cân-ı mürîdândır o

Gitdiği Hak yoludur Hazret-i şeyhim Behcet

Çok sever muhlisi Vassâf'ı ona meftûndur

Nakşbendî gülüdür Hazret-i şeyhim Behcet (Hüseyin Vassâf, 2012: 2-3, 38)

Uludağ Üniversitesi Fen-Edebiyat Fakültesi Sosyal Bilimler Dergisi Uludağ University Faculty of Arts and Sciences Journal of Social Sciences Cilt: 23 Sayı: 42 / Volume: 23 Issue: 42 
Ali Behcet Dede'nin neşesi ve muhabbetinin Hüseyin Vassâf'a yönelmesi vesilesiyle şair, Dîvân'ına onun şiirlerini de dâhil etmiş ve onları kendisine bir mükâfat olarak görmüştür:

Vasf eder dil-dâr-ı aşkı bizlere Vassâf'ımız

Bildirir esrâr-ı aşkı bizlere Vassâf'ımız

Mest eder uşşâkı dâim cân-fezâ eş'âr ile

Gösterir ezhâr-ı aşkı bizlere Vassâf'ımız

Şems-i sâfî-i ilâhîden kılıp ahz-ı ziyâ

Neşr eder envâr-ı aşkı bizlere Vassâf'ımız

Bende olmuş pîr Hüsâmeddîn'e Behcet sidk ile

Medh eder hünkâr-ı aşkı bizlere Vassâf'ımız

\section{Behcet Dede'nin Bin Cana Bedel Kahvesi}

$\mathrm{Bu}$ konunun ele alınmasina vesile olan sohbet, muhabbet ve nükte sebebi olarak unutulmaz sahnelere 1 ş̧1k tutan olay şöyle gerçekleşmiştir: "Bir gün Âsitâne-i Uşşâkîye'de hâl-i istirâhatda idik. İhvânımızdan ve şuarâdan Behcet Dede kahve pişirdi. Bizlere tevzî' etdi. Pek güzel pişirilen kahvenin husûle getirdiği te'sîr üzerine: 'Behcet Dede'nin kahvesi bin câna bedeldir' dedim. Hoşuna gitdi. Ebyât-1 âtiyeyi irticâlen söyleyiverdi. Bir hâtıra olarak yazıyorum" (Hüseyin Vassâf, 2012: 76).

“Behcet Dede'nin kahvesi bin câna bedeldir”Hüseyin Vassâf

Her katre-i feyz-âveri ummâna bedeldir

Erbâb-ı dile sor ne büyük klymeti vardır

Üstünde köpük dürr ile mercâna bedeldir

Olmaz mı lezîz pişmededir pîr ocağında

Vermez mi safâ bâde-i irfâna bedeldir

Vermezler ânın katresini âb-ı hayâta

Âşıklar için şerbet-i cânâna bedeldir

Vassâf ki bizim kahvemizi medh ede dâim

Behcet Dede bu en büyük ihsâna bedeldir

Ali Behcet Dede'nin farklı tarikat ve meşreblerdeki kişilerle ünsiyet kurduğu, onlarla latif ve nükteli sohbetlere daldığ 1 görülmektedir. Zarif kişiliği yanında izzet ve ikramı seven karaktere

Uludağ Üniversitesi Fen-Edebiyat Fakültesi Sosyal Bilimler Dergisi Uludağ University Faculty of Arts and Sciences Journal of Social Sciences Cilt: 23 Sayı: 42 / Volume: 23 Issue: 42 
sahiptir. Kendisinden yaşça büyük veya küçük her kimseye elleriyle kahve yapıp, dostlarına takdim etmesi şahsiyetinin hayata geçirilmiş hâlidir.

\section{Hüseyin Vassâf Bey'in pek sevdiği Mehmed Şemseddîn Misrî Hazretleri Dildâr-ı Şemsî̀ de Tâhir Ağa Dergâhı'ndaki bir hatırasını şu cümlelerle nakleder:}

“(Fatih) Âşık Paşa'daki Tâhir Ăga Tekyesi'ne geldik. Meşâyıh-ı Uş̧̧âkiye'nin ser-bülendi Salâhî Efendi orada medfûndur. Şeyhi Hacı Behçet Efendi ile evvelce Bursa'da görüşmüş idik. Kendisi Millet Kütübhânesinde hâfiz-ı kütübdür. Fâzll, ârif bir zâtdır. O gece cemiyetli idi. İstanbul'un en meşhûr zâkirleri geldi, neyzenler geldi, öyle bir muhabbet oldu ki tahatturu hâlâ zevkimi mucibdir. Âkbet orada da semâ'a çıkmağa mecbûr oldum. Urefâ-yı Uşşâkiyye'den ve Uşşâk-ı Misriyye'den Hüseyin Vassâf Bey'in o geceki hâli hâlâ gözümün önündedir. O'nun o geceki semâ' ’ cübbe yırtık, kendinden geçmiş bir acâyib hâldi. Ne olmaz ki, zâkirler Istanbul'un fatihi, neyzenler öyle, sesler güzel, okunan nuût ve ilâhiyyât güzel. Şeyh Efendi'nin o tehâfütüyle birer birer urbâlarını çıkarıp tedrici tedrici ilerleyerek halka-i zikre girişi, -hiç yorgunluk ârız olmayarak gençleri çok geride birakan harekâtryla 'Hayy Allah Hayy' zikr-i şerifinde husûle gelen tecelliyât-ı âşıkâne hâlâ beni müteessir etmektedir. Şu satırları yazarken bile o aşkın semeresi gözlerimden çıkıyor, ağllyorum. Hepimizi bir aşk istilâ etdi. (Sene 1919)" (Mehmed Şemseddîn, 2010: 173)

Uludağ Üniversitesi Fen-Edebiyat Fakültesi Sosyal Bilimler Dergisi Uludağ University Faculty of Arts and Sciences Journal of Social Sciences Cilt: 23 Sayı: 42 / Volume: 23 Issue: 42 


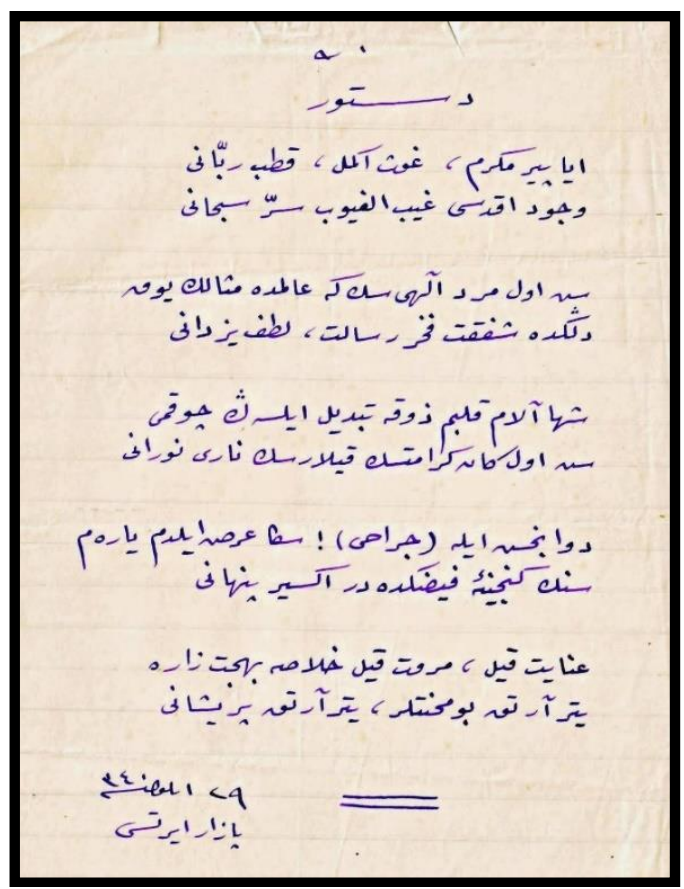

Ali Behcet Efendi'nin Nûreddîn Cerrâhi’ye Yazdığı Şiiri

Ali Behcet Dede'nin şiirleri ne yazık ki farklı yerlerde ve dağınık olarak bulunmaktadır. Kendi el yazısıyla kaleme aldığı şiirlerinden birisi de Nûreddîn Cerrâhî için yazılmış olan bir manzumesidir. Şair, onun ruhaniyetinden inayet ve mürüvvet dilemektedir. Elimizde ne yazık ki, Sefine-i Evliyâ ve Son Asır Osmanlı Şairleri adlı eserlerde kaydedilenlerin dişında tek eseri, Nûreddîn Cerrâhî Âsitânesi son postnişini Fahreddîn Efendi'nin kişisel evrakı arasında bulduğumuz Hazret-i Pîr Muhammed Nûreddîn Cerrâhî hakkında yazılmış olan kasideleridir. Hüseyin Vassâf Uşşâkî Hazretleri, Behçet Dede'nin pek çok manzumesini mahlas kaydetmeden söylediğini ve bu sebeple eş'ârının karmaşık ve perişan bir hâlde çeşitli ellerde bulunduğunu kaydediyor. Bu şiirlerinden birisi de Hazret-i Pîr'e 
bağl1lığ1 satırlarında buram buram kokan bir nutk-1 şerifidir (Nûreddîn el-Cerrâhî, 2012: 107).

Eyâ pîr-i mükerrem gavs-i ekmel kutb-ı Rabbânî

Vücûd-ı akdesi gaybe'l-guyûb-ı sirr-ı Sübhânî

Sen ol merd-i ilâhîsin ki âlemde misâlin yok

Dilinde şefkat-i fahr-i risâlet lutf-ı Yezdânî

Şehâ âlâm-ı kalbim zevke tebdîl eylesen çok mu

Sen ol kân-ı kerâmetsin kılarsin nârı nûrânî

Devâ bahşeyle Cerrâhî sana arzeyledim yârem

Senin gencîne-i feyzindedir iksîr-i pinhânî

Inâyet kul mürüvvet kll hülâsâ Behçet-i zâre

Yeter artık bu mihnetler yeter artık perîşân

\section{Behcet Dede'nin Canlara Şifa Manzumesi}

Ali Behcet Dede'nin pek çok tarikatın şartlarını yerine getirip, icazet alması ve kişiliğindeki güzellik, yaşadığı dönemde çok sevilip sayılmasına vesile olmuştur. Aslında ondaki tasavvufi coşku ve vahdet-i vücud anlayışındaki samimiyetin tezahürü olarak şiirlerindeki ilahî aşk bir parıltı gibi dikkatleri üzerine çeker. Zaman zaman rind ve zahid tiplerinin çekişmesi şiirlerinde hissedilir. Tabii ki aşktan habersiz vaiz ve zahidlere ağır eleştirisi vardır. Ali Behcet Efendi şiirlerinde "Behcet" ve "Behcet Dede" mahlaslarını kullanmıştır.

Dağınık bir hâlde farklı belge ve kaynaklarda bahsi geçen şiirlerinin önemli bir kısmının toplandığ 1 bu incelemede Dîvân-l Vassâf'ta geçen Ali Behcet Efendi ile ilgili şiirlerin tamamı buraya dâhil edilmemiştir. ${ }^{1}$

1 Ali Behcet Efendi, Eş'âr, İstanbul Üniversitesi Marmara İlahiyat Fakültesi Kütüphanesi no. 250.

Uludağ Üniversitesi Fen-Edebiyat Fakültesi Sosyal Bilimler Dergisi Uludağ University Faculty of Arts and Sciences Journal of Social Sciences Cilt: 23 Sayı: 42 / Volume: 23 Issue: 42 


\section{1- Destûr yâ Hazret-i Pîr:}

Yâ Rab nedir bu âlem

Âsâr içinde âsâr

Hayrân hüsn-i âdem

Gülzâr içinde gülzâr

*

Kllmakda kalbi hayrân

Her zerre mihr-i tâbân

Mir'ât-i pâk-i cânân

Envâr içinde envâr

*

Giymiş ser-â-ser eşyâ

Hep [ol] câma tecellâ

Her katre ayn-ı deryâ

Ebhâr içinde ebhâr

*

Bezm-i fenâ-yı kesret

Olmuş diyâr-l vahdet

Behcet bu ne hakikat

Esrâr içinde esrâr 


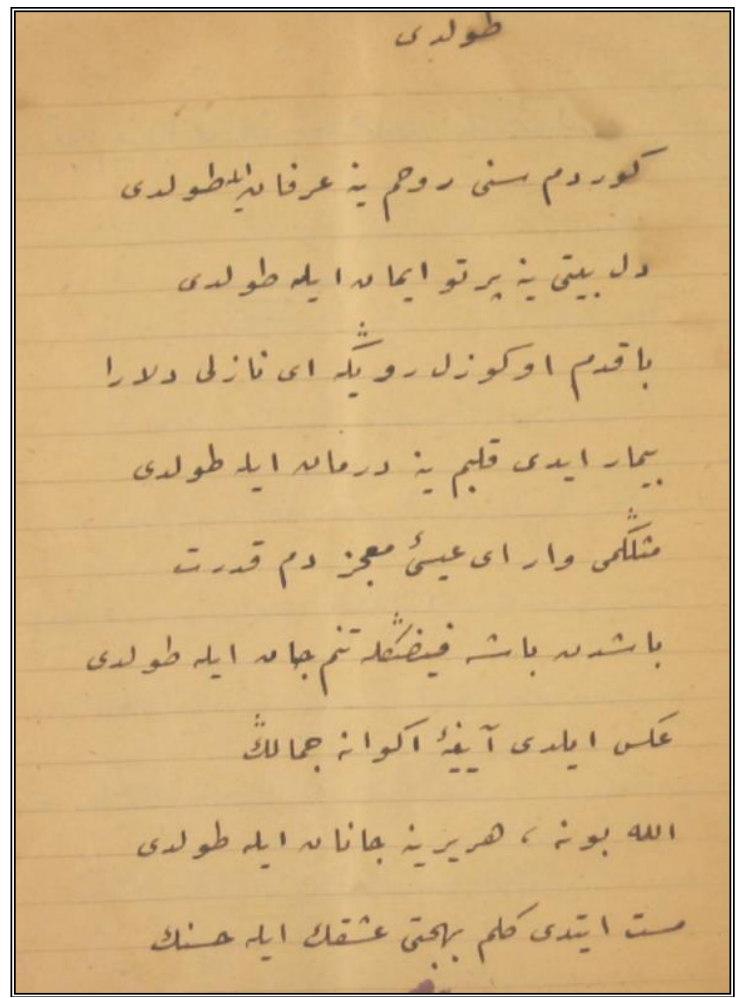

\section{2- Toldı (Doldu)}

Gördüm seni rûhum yine irfân told Dil beyti yine pertev-i îmân ile told Bakdum o güzel rûyuna ey nazlı dilârâ Bîmâr idi kalbim yine dermân ile told Mislün mi var ey Îsî-i mu'ciz-dem-i kudret Başdan başa feyzünle tenüm cân ile told 1 Aks eyledi âyîne-i ekvâna cemâlün Allah bu ne her yerine cânân ile toldı Mest itdi gülüm Behcet'i aşkın ile hüsnün Kalbim yine bak cezbe-i Rahmân ile told

Uludağ Üniversitesi Fen-Edebiyat Fakültesi Sosyal Bilimler Dergisi Uludağ University Faculty of Arts and Sciences Journal of Social Sciences Cilt: 23 Sayl: 42 / Volume: 23 Issue: 42 


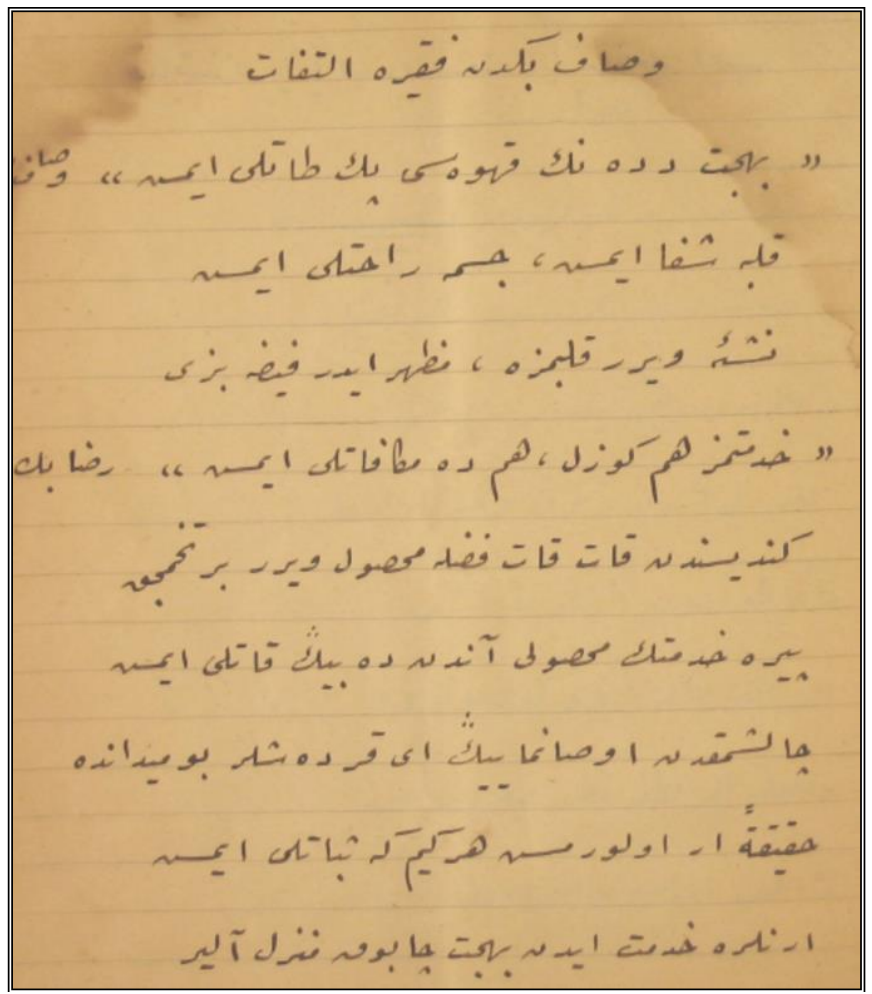

\section{3- Vassâf Bĕg’den Fakîre İltifât}

"Behcet dedenin kahvesi pek tatl imiş" Vassâf Bĕg Kalbe şifâ imiş cisme râhâtlı imiş

Neş'e virür kalbimize mazhar ider feyze bizi

"Hidmetimiz hem güzel hem de mükâfâtlı imiş" Rızâ Bĕ̆ Kendisinden kat kat fazla mahsûl virür tohumcuk Pîre hidmetün mahsîli andan da bin katlı imiş Çalışmakdan usanmayın ey kardeşler bu meydânda Hakîkaten er olurmuş her kim ki sebâtlı imiş Erenlere hidmet iden Behcet çabuk menzil alır Hidmetsizler yaya gider hidmet iden atl imiş 


\section{4- Cevâb}

Nûş idenler kahvemiz bulsun şifâ

Dest-i gamdan içmesün zehr-i cefâ

Gelmesün hîç keyfine bir dem halel

Kalbi bulsun zevk-i vahdetle safâ

Dâimâ tutsun erenler destini

Her iki âlemde görsün vefâ

Hâsılı her lutfa mazhar kılsun Hak

Şâfi'i olsun Muhammed Mustafâ

Dâimâ eyle duâ Behcet Dede

Şimdilik bu nutkıla kıl iktifâ

\section{5-Yâdigâr-ı Vassâf'a Karşı Arz-ı Teşekkür}

Hazret-i Vassâf bize bir hâme ihsân eyledi

Kıldı memnûn kalbimi lebrîz-i şükrân eyledi

Yâdigâr'ı bî-bahâdur bence kim sorsa derim

Ol kerem-kârın fakîri mâlik-i kân eyledi

Vâridât-ı tab'ım artar sâyesinde dem-be-dem

Kıldı teşvîk katre-i nâ-çîzi ummân eyledi

Her ne yazdımsa anundur medhe şâyân ancako

Ol güneşdir kim beni bir mâh-ı irfân eyledi

Öyle âli şârin Behcet gibi bir kemtere

Iltifâtı doğrusu dünyâyı hayrân eyledi 


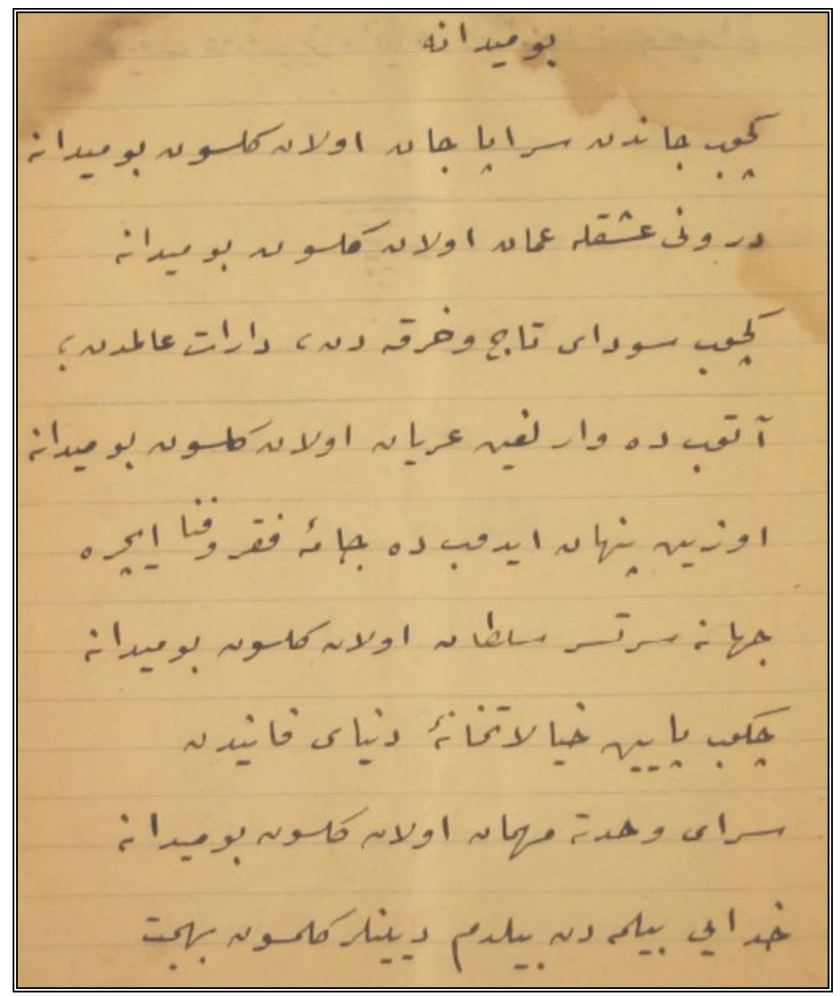

\section{6-Bu Meydâna}

Geçüp cândan ser-â-pâ cân olan gelsün bu meydâna Derûnı aşkla ummân olan gelsün bu meydâna Geçüp sevdâ-yı tâc u hırkadan dârât-ı âlemde Atup da varliğın uryân olan gelsün bu meydâna Özin pinhân idüp de câme-i fakr u fenâ içre Cihâna ser-te-ser sultân olan gelsün bu meydâna Çeküp pâyın hayâlât-nümâne-i dünyâ-yı fânîden Serây-l vahdete mihmân olan gelsün bu meydâna Hudâyı bilmeden bildüm diyenler gelsün Behcet Hakîkat ârif-i Yezdân olan gelsün bu meydâna

Uludağ Üniversitesi Fen-Edebiyat Fakültesi Sosyal Bilimler Dergisi Uludağ University Faculty of Arts and Sciences Journal of Social Sciences Cilt: 23 Sayl: 42 / Volume: 23 Issue: 42 


\section{7- Mü'min Tapar, Kâfir Tapar}

Ol büt-i nâzânıma mü'min tapar kâfir tapar Düşmen-i îmânıma mü'min tapar kâfir tapar Seyr idenler zülfini bağlar turur zünnâr-ı aşk [Esrâr]-ı devrânıma mü'min tapar kâfir tapar [Âlemi] âteş-perest-i aşkı kılmış ol perî Âteş-i sûzânıma mü'min tapar kâfir tapar [Hûrî] Yûsuf hüsnüne nisbetle bir şey mi aceb [Âteş]-i hûbânıma mü'min tapar kâfir tapar [Öyle] Fir'avn-ı letâfet kim gören hayrân olur Ol güzel sultânıma mü'min tapar kâfir tapar Behcetâ zâhid bu sırrı anlamaz hiddetlenir Hâsılı cânânıma mü 'min tapar kâfir tapar

\section{8- Değişmez}

Üftâdelerin derdini dermâna değişmez Dildâdelerin vaslını bin câna değişmez Ey nazlı perî küfr-i siyâh olsa da zülfün Âşıların ânı pertev-i îmâna değişmez Ruhsâr-ı latîfinde olan nokta-i hâli Erbâb-ı kemâl nüsha-i Kur'âna değişmez Her kim ki olur mâil-i envâr-ı cemâlin Zıll-ı tenini şems-i dırahşâna değişmez Alemde bu Behcet kulun ey nazlı dilârâ Benden olalı kendini sultâna değişmez 


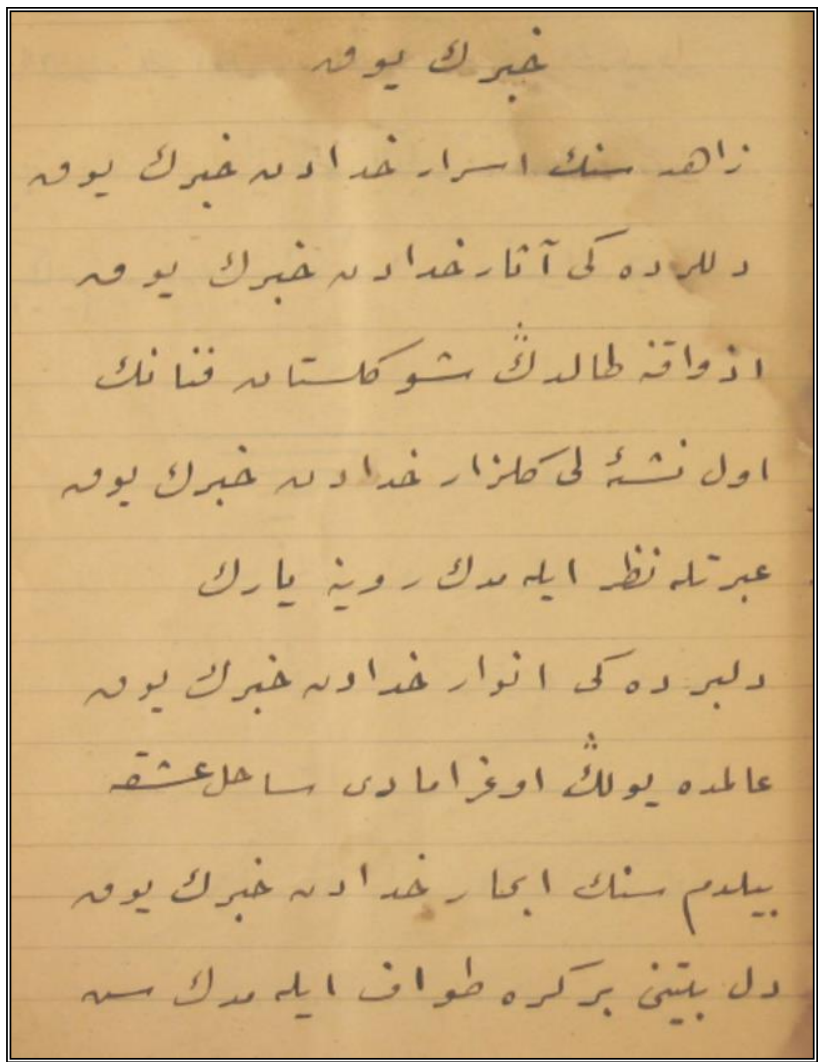

\section{9- Haberin Yok}

Zâhid senin esrâr-ı Hudâdan haberin yok

Dillerdeki âsâr-ı Hudâdan haberin yok

Ezvâkına taldın şu gülistân-ı fenânın

Ol neş'eli gülzâr-ı Hudâdan haberin yok

Ibretle nazar eylemedin rûyına yârin

Dilberdeki envâr-ı Hudâdan haberin yok

Âlemde yolun uğramadı sâhil-i aşka

Bildim senin ebhâr-ı Hudâdan haberin yok

Uludağ Üniversitesi Fen-Edebiyat Fakültesi Sosyal Bilimler Dergisi Uludağ University Faculty of Arts and Sciences Journal of Social Sciences Cilt: 23 Sayl: 42 / Volume: 23 Issue: 42 
Dil beytini bir kerre tavâf eylemedin sen

Zâhid senin ol dâr-ı Hudâdan haberin yok

Behcet Dede dir sanma geçer nakd-i ibâdet

Bil kim bunu bâzâr-ı Hudâdan haberin yok

\section{0- İmiş}

Derd-i aşkın derdlere dermân imiş

Terk-i cân uğrunda kesb-i cân imiş

Kaldı nâdân bildiğinden geçmeyen

Virdiğin ilme bedel irfân imiş

Târik-i mâl-ı cihânin bulduğu

Ser-te-ser cevher tolu bir kân imiş

Katresinden geçmeyen itdi zarar

Katreye çünki bedel ummân imiş

Bilmeyen Behcet bizi vîrân sanir

Zâhiren ma'mûr olan vîrân imiş 


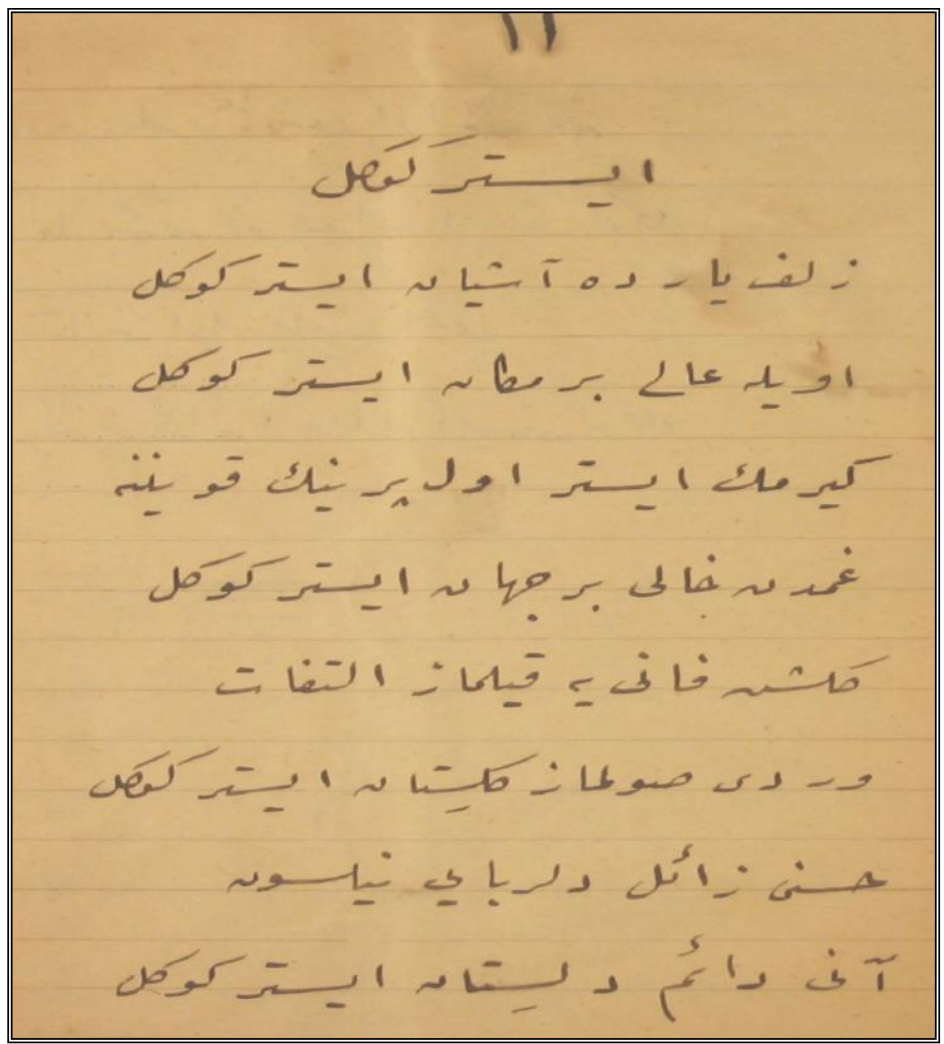

\section{1- İster Gönül}

Zülf-i yârda âşiyân ister gönül

Öyle âlî bir mekân ister gönül

Girmek ister ol perînin koynuna

Gamdan hâlî bir cihân ister ister gönül

Gülşen-i fânîye kulmaz iltifât

Verdi solmaz gülistân ister gönül

Hüsni zâil dil-rubâyı neylesün

Ânı dâim dil-sitân ister gönül

Cân u dilden âş̧ı olmuş Hâlika

Uludağ Üniversitesi Fen-Edebiyat Fakültesi Sosyal Bilimler Dergisi Uludağ University Faculty of Arts and Sciences Journal of Social Sciences Cilt: 23 Sayl: 42 / Volume: 23 Issue: 42 
Sanma başka nev-civân ister gönül Âsitâne eyle Behcet ilticâ Öyle bir dâru'l-emân ister gönül

\section{2- [Dîvânedir]}

Bak şu vâiz ehl-i aşka saldıran dîvânedir

Yokdur hiç nutkunda ma'nâ sözleri efsânedir

Her ne yapsa ehl-i dil bî-çâreyi ma'zûr görür

Kendini bilmez şarâb-l zühd ile mestânedir

Medh ider hem cenneti hem gitme dir meyhâneye

Var ise dünyâda cennet şübhesiz meyhânedir

Vasf ider hûrânı hem de sevme dir [ol] dilberi

Var ise dünyâda hûrî dilber-i şûhânedir

Zâhid-i hod-bîn bizi bilmem neden ahkar görür

Hâke de düsse yine dürdâneler dürdânedir

Mürşid-i kâmilden almış mâye-i feyz-i kemâl

Öyle şâirdir ki Behcet [her] sözi şâhânedir

Netice itibariyle Ali Behcet Dede, tasavvuf ve edebiyat tarihimizde zarafet, letafet, nükte ve derin bir muhabbetle yâd edilen, çok sevilen kişilerinden birisidir. Özellikle Mehmed Şemseddîn ve Hüseyin Vassâf onu samimi ve içli duygularla anmış, eserlerinde bu sevgiyi belirtmişlerdir. Erenlere hizmet etmeyi seyr ü sülûkta vahdete ulaşmanın, menzile hızlı kavuşmanın bir yolu olarak kabul eden Ali Behcet, şiirleri ile de gönüllere deva olmuştur.

O dönemlerde yaşayan "Behcet" ismini ve mahlasını taşıyan şair, mutasavvıf, tabib sayısı çok olduğu için bunların hayatı bazı kaynaklarda karışık bir şekilde verilmiştir.

\section{Bilgi Notu}

Makale, araştırma ve yayın etiğine uygun olarak hazırlanmıştır. Yapılan bu çalışma etik kurul izni gerektirmemektedir. 


\section{Kaynakça}

Ali Behcet Efendi. Eş'âr. İstanbul Üniversitesi Marmara İlahiyat Fakültesi Kütüphanesi. Yazmalar. No. 250.

Azamat, N. (1989). Ali Behcet Efendi. Diyanet İslam Ansiklopedisi içinde (382-383. ss.), 2, Türkiye Diyanet Vakfi Yayınları.

Batislam, H. D. (2013). Divan Edebiyatında latife ve hezl. Çukurova Üniversitesi Sosyal Bilimler Dergisi, 22(1), 229-242.

Bursalı Mehmed Tahir (1972). Osmanlı Müellifleri I. Meral Yayınevi.

Fatîn Davud (2017). Hâtimetü'l-eş'âr (Fatin Tezkiresi). Kültür ve Turizm Bakanlığı Yayınları.

Nûreddîn el-Cerrâhî (2012). Güldeste-i Hazret-i Nûreddîn el-Cerrâhî. Meşk Derneği Yayınları.

Günaydın, Y. T. (2012). Ubeydiye risalesi. Büyüyenay Yayınları.

Hüseyin Vassâf (2012). Dîvân-ı Vassâf. Kitabevi.

Hüseyin Vassâf. Sefine-i evliyâ. Süleymaniye Kütüphanesi. Yazma Bağışlar. No. 2306, 294.

Hüseyin Vassâf (2000). Sefine-i evliyâ II. (Çev: M. Akkuş, Ali Yı1maz), Kitabevi.

Levend, A. S. (1971). Divan Edebiyatında gülmece ve yergi (hezl ve hecv). Türk Dili Araştırmaları Yıllığı - Belleten içinde (37-45. ss.). Türk Tarih Kurumu Yayınları.

Mehmed Süreyya (1999). Sicill-i Osmanî II. Sebil Neşriyat.

Mehmed Şemseddîn (2010). Niyâzî-i Misrî̀nin izinde bir ömür seyahat (Dildâr-ı Şemsî). Dergâh Yayınları.

Uludağ Üniversitesi Fen-Edebiyat Fakültesi Sosyal Bilimler Dergisi Uludağ University Faculty of Arts and Sciences Journal of Social Sciences Cilt: 23 Sayı: 42 / Volume: 23 Issue: 42 
Öcalan, H. B. (2018). Mehmed Emin Kerkükî ve Eminiye Dergâhı Vakfiyesi. Uludă Üniversitesi Fen-Edebiyat Fakültesi Sosyal Bilimler Dergisi, 19(34), 215-231.

Solmaz, S. (2011). 16. asır şu'arâ tezkirelerinde nükte. Turkish StudiesInternational Periodical For The Languages, Literature and History of Turkish or Turkic, 6(2), 17-32.

Tarihi Eserleriyle Üsküdar (2017). Üsküdar Belediyesi Yayınları. 


\section{EXTENDED ABSTRACT}

In Turkish literature, apart from the works of the poets, there were also memories full of pleasant jokes, jokes and consultations and literary situations that would make them smile during their lives. During a conversation or on the occasion of a poem, he created conversations that could leave a mark in the history of literature and poems related to the subject. Gentle and witty utterances that make the reader or listener smile have survived to the present day as interesting pages of Sufi culture. Meeting the events in daily life, at least with a smile, can be considered as a necessity of life. This requirement is, in fact, a manifestation of his outlook on life. On the other side of this manifestation, there are other elements such as sadness, patience and trust. All of these reveal the philosophy of life of man. The way to meet the events with a smile is through humor.

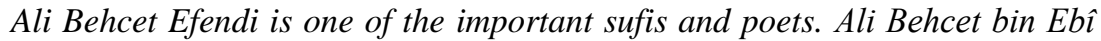
Bekr bin Hasan bin Huseyn, the poet, who is known by his tagline, was born in 1140/ 22 October 1727 in Konya. His father's name is Abu Bakr and his grandfather is Hasan Efendi. Ali Behcet Efendi received his first education from his grandfather Hasan Efendi, who was one of the scholars of the time. Later, he took lessons from Karamanl Abdullah and Abdussamed Efendi. Behcet Dede, who completed these trainings, went to Afyonkarahisar and read the works of Sufism from Mehmed Alaaddin Çelebi, who was the head of the Divane Mehmed Çelebi Lodge.

It is seen that Ali Behcet Dede established contact with people from different sects and dispositions and engaged in pleasant and witty conversations with them. In addition to his elegant personality, he has a character that loves honor and hospitality. Making coffee with his hands to anyone older or younger than him and presenting it to his friends is the realization of his personality.

Ali Behcet Dede's fulfillment of the conditions of many sects, getting ratification and the beauty in his personality; He was loved and respected during his lifetime. In fact, as a manifestation of his mystical enthusiasm and sincerity in his understanding of unity of existence, the divine love in his poems draws attention like a glow. From time to time, the conflict between rind and zahid types is felt in his poems. Of course, he has a heavy criticism of preachers and ascetics who are unaware of love. Ali Behcet Efendi used the pseudonyms "Behcet" and "Behcet Dede" in his poems.

In this study, in which a significant part of his poems, which are mentioned in different documents and sources in a scattered form, are collected; All of the poems about Ali Behcet Efendi in Divan-ı Vassaf are not included here. 
As a result, Ali Behcet Dede; He is one of the most loved people in our history of mysticism and literature, who is remembered with grace, grace, wit and deep affection. Especially Mehmed Semseddin and Huseyin Vassaf; they commemorated him with sincere and sincere feelings and wrote this love in their works. Ali Behcet, who accepted serving the saints as a way to reach unity in cruising and to reach the distance quickly, also became a cure for hearts with his poems. 